\title{
Selective Acylation of A-Ring Precursors of Vitamin D Using Enzymes in Organic Solvents ${ }^{1}$
}

\author{
Susana Fernández, ${ }^{2 a, b}$ Miguel Ferrero, ${ }^{2 a}$ Vicente Gotor, ${ }^{*, 2 c}$ and William H. Okamura ${ }^{*, 2 a}$ \\ Department of Chemistry, University of California, Riverside, California 92521, and Departamento de \\ Química Orgánica e Inorgánica, Universidad de Oviedo, 33071 Oviedo, Spain
}

\begin{abstract}
Whereas Chromobacterium viscosum lipase (CVL) catalyzes selectively the acylation of the C-5 hydroxyl of the three stereoisomeric vitamin D A-ring precursors $2 \mathbf{a}, 3 \mathbf{a}$ and $\mathbf{3 b}$, only the C-3 hydroxyl of the fourth stereoisomer $\mathbf{2 b}$ is acylated under the same conditions in organic solvent. In a convenient application, the racemic vitamin D A-ring precursor 4, possessing only the C-5 hydroxyl, was resolved using suitable conditions identified from the studies of 2 and $\mathbf{3}$.
\end{abstract}

\section{Introduction}

The metabolism of vitamin $\mathrm{D}_{3}(\mathbf{1 a})$ involves $\mathrm{C}-25$ hydroxylation in the liver to produce 25 -hydroxyvitamin $\mathrm{D}_{3}$ (1b) followed by C-1 hydroxylation in the kidney to give 1 $\alpha, 25$-dihydroxyvitamin $D_{3}\left(1 \mathrm{c}, 1 \alpha, 25-(\mathrm{OH})_{2}-\mathrm{D}_{3}\right)$, the hormonally active form of vitamin $\mathrm{D}^{3}$ In addition to its long known calcemic action, a number of biological activities including those related to cancer, ${ }^{4}$ skin diseases, ${ }^{5}$ immunomodulatory effects, ${ }^{6}$ and Alzheimer's disease ${ }^{7}$ have been linked to this hormone. Accordingly, the synthesis of new analogues has drawn increasing attention from the standpoint of developing chemotherapeutically useful drugs. Substantial effort has also been directed toward developing cogent structure-function relationships to develop an improved paradigm for more effectively designing target analogues. For example, a number of A-ring carbinol diastereoisomers of $1 \alpha, 25$ $(\mathrm{OH})_{2}-\mathrm{D}_{3}$ (1c) recently synthesized in our laboratory ${ }^{8}$ proved highly informative in probing the structural

${ }^{\otimes}$ Abstract published in Advance ACS Abstracts, September 1, 1995.

(1) This is paper 49 in the series Studies of Vitamin D (Calciferol) and Its Analogues. For part 48, see: Maynard, D. F.; Trankle, W. G. Norman, A. W.; Okamura, W. H. J. Med. Chem. 1994, 37, 2387.

(2) (a) Department of Chemistry, University of California, Riverside. (b) The major portion of the results of this investigation, conducted at the University of California, Riverside, is described in detail as part of the Doctoral Thesis of S. Fernández (Ph.D. Dissertation, 1994, Universidad de Oviedo, Spain). (c) Departamento de Química Orgánica e Inorgánica, Universidad de Oviedo, Spain.

(3) (a) Norman, A. W.; Bouillon, R.; Thomasset, M., Eds. Vitamin D, A Pluripotent Steroid Hormone: Structural Studies, Molecular Endocrinology and Clinical Applications; Walter de Gruyter: Berlin New York, 1994. (b) Bouillon, R.; Okamura, W. H.; Norman, A. W. Endocr. Rev. 1995, 16, 200

(4) (a) Eisman, J. A. In Bone and Mineral Research; Heersche, J. N. M., Kanis, J. A., Eds.; Elsevier: Amsterdam, 1994; Vol 2, p 45. (b) Gross, M.; Kost, S. B.; Ennis, B.; Stumpf, W.; Kumar, R. J. Bone Miner. Res. 1986, 1, 457. (c) Honma, F.; Hozumu, M.; Abe, E.; Konno, K.; Fukushima, M.; Hata, S.; Nishii, Y.; DeLuca, H. F.; Suda, T. Proc. Natl. Acad. Sci. U.S.A. 1983, 80, 201. (d) Koeffler, H. P.; Amatruda, T. Ikekawa, N.; Kobayashi, Y.; DeLuca, H. F. Cancer Res. 1984, 44, 5624 (e) Munker, R.; Norman, A. W.; Koeffler, H. P. J. Clin. Invest, 1986, 78,424 .

(5) (a) MacLaughlin, J. A.; Gange, W.; Taylor, D.; Smith, E.; Holick M. F Proc. Natl Acad. Sci. USA $1985,82,5409$ (b) Morimoto $S$. Yoshikawa, K.; Kozuka, T.; Kitano, Y.; Imanaka, S.; Fukuo, K.; Koh, E.; Onishi, T.; Kumahara, Y. Calcif. Tissue Int. 1986, 39, 209. (c) Morimoto, S.; Onishi, T.; Imanaka, S.; Yukawa, H.; Kosuka, T.; Kitano, Y.; Yoshikawa, Y. Calcif. Tissue Int. 1986, 38, 119. (d) Kragballe, K. J. Cell. Biochem. 1992, 49, 46.

(6) (a) Lemire, J. M. J. Cell. Biochem. 1992, 49, 26. (b) Amento, E. P. Steroids 1987, 49,55 .

(7) (a) Saporito, M. S.; Brown, E. R.; Hartpence, K. C.; Wilcox, H. M.; Vaught, J. L.; Carswell, S. Brain Res. 1994, 633, 189. (b) Saporito, M. S.; Wilcox, H. M.; Hartpence, K. C.; Lewis, M. E.; Vaught, J. L.; Carswell, S. Exp. Neurol. 1993, 123, 295. (c) Carswell, S. Exp. Neurol. $1993,124,36$. demands of the nuclear vitamin $D$ receptor, which mediates the genomic effects of vitamin $\mathrm{D}$. It has also been determined that the C-1 epimer of $1 \alpha, 25-(\mathrm{OH})_{2}-\mathrm{D}_{3}$ is a potent inhibitor of the nongenomic calcium transport actions of $1 \alpha, 25-(\mathrm{OH})_{2}-\mathrm{D}_{3}(\mathbf{1 c}),{ }^{8 b, c, d}$ and it has been found that the C-3 epimer is a natural metabolite of this same hormone. 9 In addition, the synthesis of isotopically labeled derivatives of vitamin $D_{3}$ and its metabolites has provided convenient research tools for evaluation of biosynthetic pathways as well as chemical processes (e.g., $[1,7]$-sigmatropic hydrogen shifts). ${ }^{10}$

A general approach leading to the synthesis of vitamin $\mathrm{D}$ analogues involves coupling of an appropriate $\mathrm{CD}$-ring fragment and A-ring synthons such as enynes 2,3 , and 4 which have been derived from $(S)$ - or $(R)$-carvone $(5)^{8 \mathrm{a}, 11}$ or hydroxy ketal $6^{10 a}$ (Chart 1). Recently, there emerged a need in our laboratory for preparing A-ring synthons such as 2 and 3 modified selectively at their carbinol centers, as well as for preparing large amounts of racemic and enantiomerically pure A-ring enynol 4. Accordingly, we began an evaluation of enzymatic procedures for effecting these transformations. Lipases and proteases have been used effectively in regioselective acylation of natural products with various hydroxyl groups and in the resolution of racemic pharmacological compounds. ${ }^{12}$ Here we report a systematic study of the enzyme-catalyzed acylation in organic solvents of the four A-ring diastereoisomers $2 \mathbf{a}, \mathbf{2 b}, \mathbf{3 a}$, and $\mathbf{3 b}$ and the novel finding that the cis stereoisomer $\mathbf{2 b}$ is uniquely acylated at its allylic (C-3) hydroxyl position, just the reverse of the nonallylic (C-5) acylation observed for $\mathbf{2 a}, \mathbf{3 a}$, and $\mathbf{3 b}$. This acyla-

(8) (a) Muralidharan, K. R.; de Lera, A. R.; Issaeff, S. D.; Norman A. W.; Okamura. W. H. J. Org. Chem. 1993, 58, 1895. (b) Norman, A. W.; Bouillon, R.; Farach-Carson, M. C.; Bishop, J. E.; Zhou, L.-X.; Nemere, I.; Zhao, J.; Muralidharan, K. R.; Okamura. W. H. J. Biol. Chem. 1993, 268, 20022. (c) Baran, D. T. J. Cell. Biochem. 1994, 56, 303. (d) Baran, D. T.; Ray, R.; Sorensen, A. M.; Honeyman, T.; Holick, M. F. J. Cell. Biochem. 1994, 56, 510 .

(9) Reddy, G. S.; Muralidharan, K. R.; Okamura, W. H.; Tserng, K. Y.; McLane, J. A. In Vitamin D, A Pluripotent Steroid Hormone: Structural Studies, Molecular Endocrinology and Clinical Applications; Norman, A. W., Bouillon, R., Thomasset, M., Eds.; Walter de Gruyter: Berlin-New York, 1994; p 172.

(10) (a) Okamura, W. H.; Elnagar, H. Y.; Ruther, M.; Dobreff, S. J. Org. Chem 1993, 58, 600. (b) Curtin, M. L.; Okamurg, W. H. $J$ Am. Chem. Soc. 1991, 113, 6958. (c) Norman, A. W.; Okamura, W. H.; Farach-Carson, M. C.; Allewaert, K.; Branisteanu, D.; Nemere, I.; Muralidharan, K. R.; Bouillon, R. J. Biol. Chem. 1993, 268, 13811.

(11) (a) Okamura, W. H.; Aurrecoechea, J. M.; Gibbs, R. A.; Norman, A. W. J. Org. Chem. 1989, 54, 4072. (b) Aurrecoechea, J. M.; Okamura, W. H. Tetrahedron Lett. 1987, $28,4947$.

(12) Faber, K. Biotransformations in Organic Chemistry, 2nd ed.; Springer-Verlag: Berlin, 1995. 


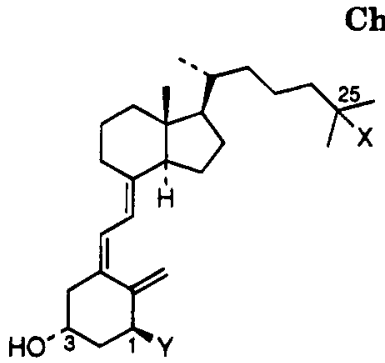

1a, $X=Y=H$

b, $X=O H ; Y=H$

c, $X=Y=O H$

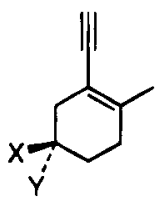

4a, $X=\mathrm{H} ; Y=\mathrm{OH}[(S)-(-)]$

b, $X=O H ; Y=H[(R)-(+)]$ 5a, $X=H ; Y=C\left(\mathrm{CH}_{2}\right) \mathrm{CH}_{3}[(S)-(+)]$ b, $X=\mathrm{C}\left(\mathrm{CH}_{2}\right) \mathrm{CH}_{3} ; Y=\mathrm{H}[(R)-(-)]$

a, $R=O H ; R^{\prime}=H$

b. $R=H_{;} R^{\prime}=O H$

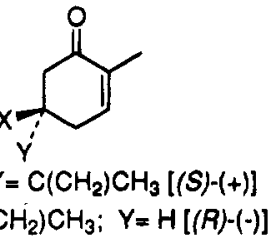

6

Scheme 1

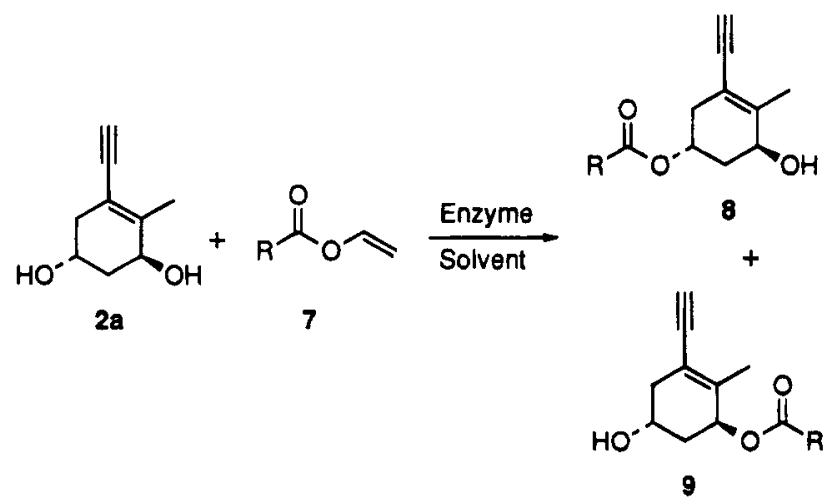

[a, R=Me; b, R=Et; $c, R=P r ; d, R=\mathrm{CH}_{2} \mathrm{Cl} ; \boldsymbol{\theta}, \mathrm{R}=\mathrm{Ph}$ ]

tion procedure has also been extended to an application to the resolution of the related racemic synthon ( \pm )-4.

\section{Results and Discussion}

Acylation of 2a. The studies of enzymatic acylation were first focused on the A-ring fragment 2a, which possesses the natural carbinol stereochemistry $(3 S, 5 R) .{ }^{8 \mathrm{a}, 11}$ Initial experiments concerned screening lipases [Candida cylindracea lipase (CCL), Pseudomonas cepacia lipase (PSL), Chromobacterium viscosum lipase (CVL), porcine pancreatic lipase (PPL), and Candida antarctica lipase (CAL)] and proteases [subtilisin and papain] as catalysts to determine which enzyme gives the best regioselectivity for acylation (Scheme 1). For the initial studies vinyl acetate was used as the acetylating agent and solvent, and the results are summarized in Table 1.

Of the enzymes studied, CVL gives the best result. It catalyzes acetylation of the C-5- $(R)$ hydroxyl group with excellent regioselectivity and in good yield. CCL also revealed some preference for the same hydroxyl, but the selectivity is lower. When CAL or PSL was used, acetylation occurred with a slight preference for C-3 instead of C-5. As one can see in Table 1, PPL and papain gave only trace amounts of products $8 \mathbf{a}$ and $9 \mathbf{a}$. In the case of the protease subtilisin no reaction occurred even after long reaction times.

Table 1. Reaction of 2a with Vinyl Acetate 7a Catalyzed by Enzymes ${ }^{a}$

\begin{tabular}{lrccc}
\hline enzyme & $t(\mathrm{~h})$ & convn $(\%)^{b}$ & $\mathbf{8 a}(\%)^{b}$ & $\mathbf{9 a}(\%)^{b}$ \\
\hline CCL & 115 & 82 & 67 & 33 \\
PSL & 115 & 85 & 47 & 53 \\
CVL & 96 & 72 & $>95$ & $<5$ \\
PPL & 137 & $<10$ & trace & trace \\
papain & 93 & $<10$ & trace & trace \\
CAL $^{c}$ & 91 & 56 & 37 & 63 \\
subtilisin $^{6}$ & 71 & 0 & &
\end{tabular}

${ }^{a}$ These processes were carried out at room temperature. ${ }^{b} \mathrm{Cal}-$ culated by ${ }^{1} \mathrm{H}-\mathrm{NMR}$ analysis. ${ }^{c} \mathrm{SP} 435 \mathrm{~L}$.

Table 2. Reaction of 2a with Vinyl Esters 7a-e Catalyzed by $\mathrm{CVL}^{a}$

\begin{tabular}{clcrccc}
\hline entry & $\mathrm{R}$ & solvent & $t(\mathrm{~h})$ & convn $(\%)^{b}$ & $\mathbf{8}(\%)^{b, c}$ & $\mathbf{9 ( \% ) ^ { b }}$ \\
\hline $\mathbf{a}$ & $\mathrm{Me}$ & none & 24 & 100 & $93(90)$ & 7 \\
$\mathbf{b}$ & $\mathrm{Et}$ & none & 40 & 100 & $87(90)$ & 13 \\
c & $\mathrm{Pr}$ & none & 96 & 100 & $84(85)$ & 16 \\
d & $\mathrm{ClCH}_{2}$ & THF & 45 & 100 & $85(70)$ & 15 \\
e & $\mathrm{Ph}$ & $\mathrm{THF}$ & 113 & 0 & &
\end{tabular}

${ }^{a}$ These processes were carried out at $45^{\circ} \mathrm{C}$. ${ }^{b}$ Calculated by ${ }^{1} \mathrm{H}$ NMR analysis. ${ }^{c}$ Values in parentheses represent isolated yields of 8 .

To more fully investigate the reaction conditions for this enzymatic acetylation, a variety of solvents were tested with two goals in mind. The first was to find the best enzyme-solvent system for acetylation of the C-5$(R)$ hydroxyl group. The second goal was to find conditions, if possible, for the regioselective acylation of the (3S)-hydroxyl group. Of the enzyme-solvent systems studied, CVL in THF gave the highest regioselectivity toward the C-5-( $R$ ) hydroxyl (8a), but the use of vinyl acetate as solvent afforded better results. CAL shows greater selectivity $(74 \%$ of $\mathbf{8 a}, 26 \%$ of $9 a$ ) toward position 5 when the solvent is benzene. However, the opposite regioselectivity ( $39 \%$ of $8 \mathbf{a}, 61 \%$ of $9 \mathbf{a}$ ) somewhat favoring the C-3 hydroxyl group is achieved when isopropyl ether is used as the solvent, but conditions for selective acylation at C-3 could not be defined.

To evaluate other acylating agents and take advantage of the observation that CVL shows excellent acetylation selectivity and yield with vinyl acetate as solvent, the reaction of $2 \mathrm{a}$ with other vinyl esters was studied. As shown in Table 2 , the reactions were run at $45^{\circ} \mathrm{C}$ using a ratio of vinyl ester to diol of $\sim 10: 1$. The vinyl ester was used as the solvent whenever possible, but THF was added as solvent in those cases where the high boiling point of the acylating agent rendered cumbersome its removal from the product mixture. Acylation occurred selectively at the C-5-( $R$ ) hydroxyl except when vinyl benzoate was used wherein esterification did not take place even after heating at $45{ }^{\circ} \mathrm{C}$ for several days.

In summary, the results indicate that CVL will allow regioselective incorporation of a variety of acyl moieties at the C-5- $(R)$ hydroxyl of 2a. While these results indicate that vinyl esters are generally suitable, acid anhydrides gave poor selectivity and afforded low conversion. Selective acylation at C-3 of 2 a could not be effectively achieved.

Acylation of the Stereoisomers of 2a: Its Enantiomer $3 b$ and Cis Stereoisomers $3 a$ and $2 b$. Table 3 summarizes the results obtained for the acylation of the enantiomer of $(3 S, 5 R)-2 \mathrm{a}$, namely $(3 R, 5 S)-3 \mathbf{b}^{8 \mathrm{a}}$ shown in Scheme 2. For direct comparison to the data in Table 2 for 2a, CVL was also used and it was determined that the reaction with $\mathbf{3 b}$ also proceeds with quantitative 
Table 3. Reaction of 3b with Vinyl Esters 7a-e Catalyzed by CVL ${ }^{a}$

\begin{tabular}{clcrccc}
\hline entry & $\mathbf{R}$ & solvent & $t(\mathrm{~h})$ & convn $(\%)^{b}$ & $\mathbf{1 0}(\%)^{b, c}$ & $\mathbf{1 1 ( \% ) ^ { b }}$ \\
\hline a & $\mathrm{Me}$ & none & 7 & 100 & $94(88)$ & 6 \\
b & $\mathrm{Et}$ & none & 7 & 100 & $94(95)$ & 6 \\
c & $\mathrm{Pr}$ & none & 5 & 100 & $95(70)$ & 5 \\
d & $\mathrm{ClCH}_{2}$ & $\mathrm{THF}$ & 21 & 100 & $78(71)$ & 22 \\
e & $\mathrm{Ph}$ & $\mathrm{THF}$ & 119 & 100 & $92(70)$ & 8
\end{tabular}

a These processes were carried out at room temperature. ${ }^{b} \mathrm{Cal}$ culated by ${ }^{1} \mathrm{H}-\mathrm{NMR}$ analysis. ${ }^{c}$ Values in parentheses represent isolated yields of 10 .

\section{Scheme 2}

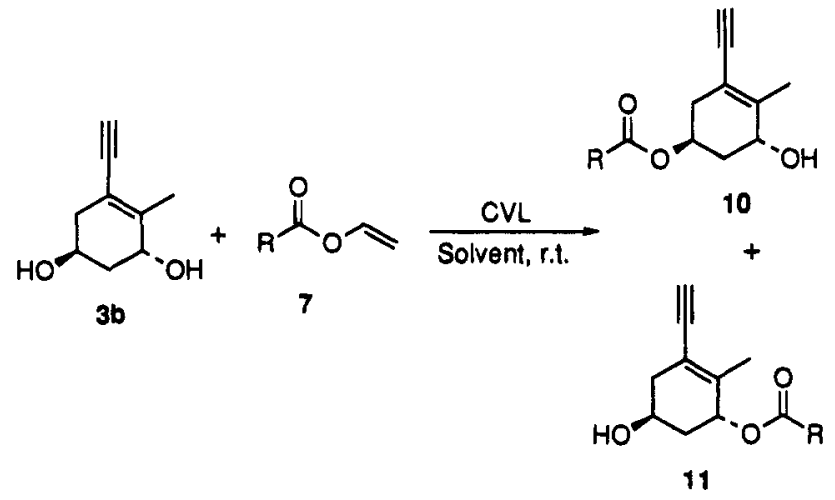

[a, R=Me; b, R=Et; c, R=Pr; d, R=CH $\left.\mathrm{CH}_{2} \mathrm{Cl} ; \boldsymbol{e}, \mathrm{R}=\mathrm{Ph}\right]$

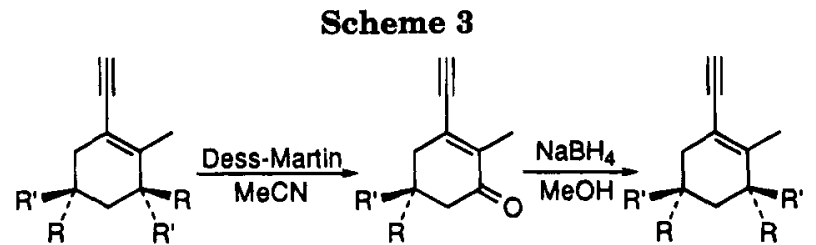
2a, $R=O H_{;} R^{\prime}=H$
12a, $R=O H ; R^{\prime}=H$
2b, $R=O H ; R^{\prime}=H$
3b, $R=H ; R^{\prime}=O H$
b. $R=H ; R^{\prime}=O H$
3a, $R=H: R^{\prime}=O H$

regioselectivity toward the hydroxyl group at the C-5 position. The acylation reaction is however faster for $\mathbf{3 b}$ with vinyl acetate than its enantiomer 2a. Complete conversion of $\mathbf{3 b}$ with vinyl acetate at room temperature occurs in $7 \mathrm{~h}$, while that of enantiomer $2 \mathrm{a}$ requires heating of the reaction mixture at $45^{\circ} \mathrm{C}$ for $24 \mathrm{~h}$ (see entry $a$ in Table 2 versus entry a in Table 3 ). The regioselectivities obtained with the different vinyl esters are somewhat higher than for $\mathbf{2 a}$. Significantly, $\mathbf{3 b}$ reacts with vinyl benzoate at room temperature, which contrasts to the lack of reaction of enantiomer $2 a$ under somewhat more forcing conditions (room temperature versus $45^{\circ} \mathrm{C}$ ).

Tables 4 and 5 and Schemes 4 and 5 summarize similar acylation studies of the cis stereoisomers $(3 S, 5 S)$ $3 \mathbf{a}$ and $(3 R, 5 R)-2 \mathbf{b}$, respectively, which were synthesized as shown in Scheme 3 . In the latter scheme, selective oxidation of the C-3 allylic alcohol of $\mathbf{2 a}$ and $\mathbf{3 b}$ using the Dess-Martin reagent ${ }^{13}$ afforded ketones $12 \mathbf{a}$ and $12 b$, which were reduced in a conventional fashion to the requisite cis diols $\mathbf{2 b}$ and $\mathbf{3 a}$, respectively. There was obtained $\sim 3: 1$ cis to trans selectivity (separable by HPLC) in both cases.

As shown in Table 4, CVL-catalyzed acetylation of the cis diol 3a occurred with complete regioselectivity (100\%)

(13) (a) Dess, D. B.; Martin, J. C. J. Org. Chem. 1983, 48, 4155. (b) Dess, D. B.; Martin, J. C. J. Am. Chem. Soc. 1991, 113, 7277. (c) Ireland, R. E.; Liu, L. J. Org. Chem. 1993, 58, 2899.
Table 4. Reaction of 3a with Vinyl Esters 7a,c-d Catalyzed by CVL ${ }^{a}$

\begin{tabular}{clcccccc}
\hline entry & \multicolumn{1}{c}{$\mathrm{R}$} & solvent & $t(\mathrm{~h})$ & $\begin{array}{c}\text { convn } \\
(\%)^{b}\end{array}$ & $\begin{array}{c}13 \\
(\%)^{b, c}\end{array}$ & $\begin{array}{c}14 \\
(\%)^{b}\end{array}$ & $\begin{array}{c}15 \\
(\%)^{b}\end{array}$ \\
\hline a & $\mathrm{Me}$ & none & 21 & 100 & $100(90)$ & 0 & 0 \\
c & $\mathrm{Pr}$ & none & 48 & 100 & $98(89)$ & 0 & 2 \\
d & $\mathrm{ClCH}_{2}$ & THF & 23 & 100 & $93(86)$ & 7 & 0
\end{tabular}

$a$ These processes were carried out at room temperature. ${ }^{b} \mathrm{Cal}$ culated by ${ }^{1} \mathrm{H}-\mathrm{NMR}$ analysis. ${ }^{c}$ Values in parentheses represent isolated yields of 13 .

Table 5. Reaction of $\mathbf{2 b}$ with Vinyl Esters 7a,c-d Catalyzed by CVLa

\begin{tabular}{|c|c|c|c|c|c|c|c|}
\hline entry & $\mathbf{R}$ & solvent & $t(h)$ & $\begin{array}{c}\text { convn } \\
(\%)^{b}\end{array}$ & $\begin{array}{c}16 \\
(\%)^{b}\end{array}$ & $\begin{array}{c}17 \\
(\%)^{b, c}\end{array}$ & $\begin{array}{c}18 \\
(\%)^{b}\end{array}$ \\
\hline $\mathbf{a}$ & $\mathrm{Me}$ & & 48 & 100 & 1 & $95(80)$ & 4 \\
\hline $\mathbf{c}$ & $\operatorname{Pr}$ & none & 144 & 100 & $<2$ & $>98(90)$ & 0 \\
\hline d & $\mathrm{ClCH}_{2}$ & THF & 92 & 100 & 2.5 & $91(85)$ & 6.5 \\
\hline
\end{tabular}

a These processes were carried out at room temperature. ${ }^{b} \mathrm{Cal}$ culated by ${ }^{1} \mathrm{H}-\mathrm{NMR}$ analysis. ${ }^{c}$ Values in parentheses represent isolated yields of $\mathbf{1 7}$.

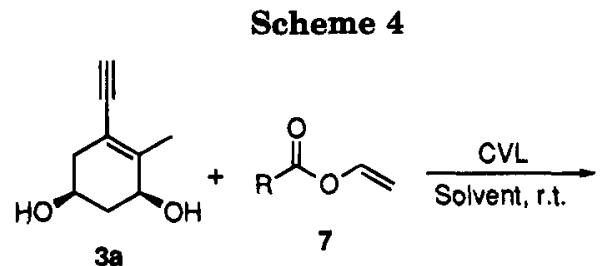<smiles></smiles>

13

14

15

[a, R=Me; $\left.c, R=P r ; d, R=C H_{2} C l\right]$

Scheme 5
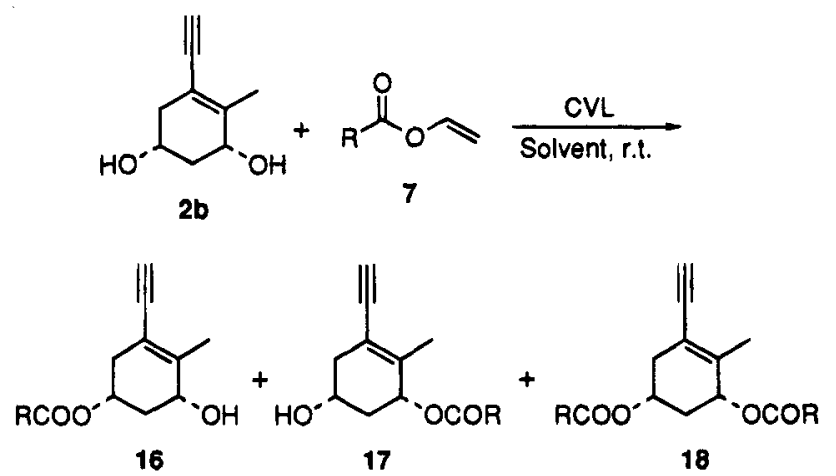

[a, R=Me; c, R=Pr; d, R=CH $\mathrm{CH}_{2} \mathrm{Cl}$

toward the hydroxyl group at the C-5 position. Excellent results were also obtained with vinyl butyrate and vinyl chloroacetate $(\sim 100 \%$ and $93 \%$ regioselectivity, respectively).

As shown in Table 5, parallel acylation of the remaining stereoisomer cis diol $\mathbf{2 b}$ proved most interesting wherein C-3 hydroxylation now dominates, just the opposite of its three C-3,5 stereoisomers $\mathbf{2 a}, \mathbf{3 a}$, and $\mathbf{3 b}$. The selectivity and rate was qualitatively only slightly lower than that for 3a. Vinyl butyrate, used as both the acylating reagent and solvent, exhibited complete regioselectivity toward the hydroxyl group at the C-3 position. 


\section{Scheme 6}<smiles>C#CC1=C(C)CC[C@@H](O)C1</smiles>

$( \pm)-4$

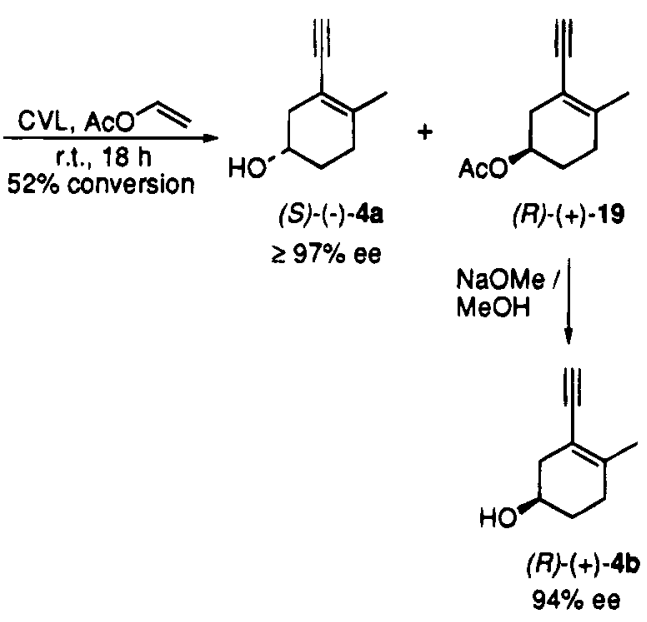

From the results of the acylation of the four stereoisomers $2 \mathbf{a}, \mathbf{2 b}, \mathbf{3 a}$, and $\mathbf{3 b}$, it is clear that a hydroxyl group with the $\mathrm{C}-5-(S)$ or $\beta$ orientation ${ }^{14}$ is acylated considerably more rapidly than that with the corresponding $(R)$ or $\alpha$ orientation (cf. $3 \mathbf{a}>2 \mathbf{a}$; and also $(R)-(+)-4$ $>(S)-(-)-4$ as discussed below). It also seems apparent that a hydroxyl with the $\mathrm{C}-3-(R)$ or $\alpha$ orientation is acylated more easily than that with the $\mathrm{C}-3-(S)$ or $\beta$ orientation, but selective acylation at a $\mathrm{C}-5-(S)$ or $\beta$ orientation is more important (cf. acylation at C-5 dominates in the case of $\mathbf{3 b}$ ). This also rationalizes why the selectivities for C-5 acylation are greater for substrate 3a (Table 4) than for substrate 3b (Table 3), but the differences are not large. Only in the case of isomer $\mathbf{2 b}$ $(3 R, 5 R)$, which possesses the $\mathrm{C}-5-(R)$ configuration (which attenuates strongly C-5 acylation) and the C-3- $(R)$ configuration (which enhances C-3 acylation), do both hydroxyls work in concert to enhance C-3 acylation. These results could be useful in gleaning information about the steric requirements of the enzyme active site.

Resolution of A-Ring Synthon ( \pm -4. Given the difference in reaction times observed for the enantiomers $2 \mathbf{a}$ and $\mathbf{3 b}$ as well as $\mathbf{2 b}$ and $3 \mathbf{a}$, we examined the possibility that CVL could be useful in the kinetic resolution of racemic A-ring fragment 4. Recently, this laboratory reported that 4-hydroxycyclohexanone (6) could be transformed to optically pure $(S)-(-)-4$, via racemic 4 through initial formation of its $\left(1 S, 1^{\prime} S\right)$ and $\left(1 R, 1^{\prime} S\right)$ carbamates using $(S)$-naphthyl isocyanate, followed by separation via HPLC and then deprotection of the $\left(1 S, 1^{\prime} \mathrm{S}\right)$ carbamate. ${ }^{10 \mathrm{a}}$ Using CVL, the resolution of $( \pm)-4$ affording the natural enynol (-)-isomer could be nicely effected in only one step (Scheme 6). The reaction was carried out at room temperature using CVL with vinyl acetate acting as both acylating agent and solvent. After $18 \mathrm{~h}, \mathrm{GC}$ analysis revealing $52 \%$ conversion, the reaction was stopped and flash chromatography (silica gel, 20\% EtOAc-hexanes) of the product mixture gave the enantiomerically pure $(S)-(-)-4$ in high yield $(97 \%$, $\left.\geq 97 \% \mathrm{ee}^{15}\right)$. The remaining acetate $(99 \%$ yield) was treated with sodium methoxide to afford $(R)-(+)-4$ which

14) Note that $\alpha$ (down) and $\beta$ (up) have their usual definitions for all of the structures described in this paper except for 1 (i.e., vitamin $\mathrm{D}_{3}$ and its metabolites). Because vitamin $\mathrm{D}$ is typically drawn in its more stable nonsteroidal, 6-s-trans conformation, the $\alpha^{\prime} \mathrm{s}$ (up) and $\beta$ 's (down) are reversed in orientation for its A ring only.

(15) Enantiomeric purities indicated as ee $\geq 97 \%( \pm 3 \%$ by NMR analysis) signifies that only one enantiomer was detected even at high spectrum amplitude. had $94 \%$ ee. Thus, this route provides a convenient direct route to $4 \mathrm{a}$ possessing the natural $\mathrm{C}-5$ configuration (corresponding to the steroidal $3 \beta$-hydroxyl) of vitamin $\mathrm{D}_{3}$.

\section{Summary}

Evaluation of the enzymatic acylation of the vitamin D A-ring enynes $2 a, 2 b, 3 a$, and $3 \mathbf{b}$ revealed that CVL is the best enzyme for effecting practical levels of regioselectivity, and the novel finding was made that only the cis diol $\mathbf{2 b}$ is acylated at the allylic C-3 hydroxyl, the other stereoisomers being acylated at C-5. Direct application of this method leads to convenient kinetic resolution of fragment ( \pm )-4. An explanation for the origin of the selectivity exerted by CVL for the stereoisomeric series 2a, 2b, 3a, and $\mathbf{3 b}$ awaits further evaluation.

\section{Experimental Section ${ }^{16}$}

General. Subtilisin (type VIII bacterial), papain, porcine pancreatic lipase, PPL, (type II crude), and Candida cylindracea lipase, CCL, (type VII crude), were obtained from Sigma Chemical Co. Pseudomonas cepacia lipase, PSL, was obtained from Amano Pharmaceutical Co. Chromobacterium viscosum lipase, CVL, was from Genzyme Co. Candida antarctica lipase, CAL SP 435L, was from Novo Nordisk Co. In all cases, crude product mixtures were subjected by ${ }^{1} \mathrm{H}-\mathrm{NMR}$ integration analysis $( \pm 3 \%)$ to determine percent conversion and relative percentages of esterified products as summarized in Tables $1-5.16 \mathrm{~b}$

Enzymatic Acetylation of (3S,5R)-2a in Vinyl Acetate. To a solution of $2 \mathrm{a}(10 \mathrm{mg}, 0.066 \mathrm{mmol})$ in vinyl acetate $(2.5$ $\mathrm{mL}$ ) was added one of the following enzymes: $300 \mathrm{mg}$ of CCL, PSL, PPL, or papain; $10 \mathrm{mg}$ of CVL; $60 \mathrm{mg}$ of subtilisin; or 45 $\mathrm{mg}$ of CAL. The suspension was shaken at room temperature, and the progress of the reaction was followed by TLC until no further reaction was apparent. After removal of the enzyme by filtration and evaporation of the solvent and ${ }^{1} \mathrm{H}-\mathrm{NMR}$ analysis, the residual mixture was purified by HPLC (Rainin Microsorb, $1 \times 25 \mathrm{~cm}, 5 \mu \mathrm{m}$ silica gel column, $25 \%$ ethyl acetate/hexanes, $4 \mathrm{~mL} / \mathrm{min}$ ) to give monoacetates $8 \mathrm{a}$ and $9 \mathbf{a}$. The results are summarized in Table 1. 8a: ${ }^{1} \mathrm{H}$ NMR $\delta 2.02$ $\left(\mathrm{s}, 3 \mathrm{H}, \mathrm{C}_{2}-\mathrm{Me}\right), 2.04(\mathrm{~s}, 3 \mathrm{H}, \mathrm{Me}), 2.20\left(\mathrm{dd}, 1 \mathrm{H}, \mathrm{H}_{6},{ }^{2} J_{\mathrm{HH}}=17.1\right.$, $\left.{ }^{3} J_{\mathrm{HH}}=7.3 \mathrm{~Hz}\right), 2.61\left(\mathrm{dd}, 1 \mathrm{H}, \mathrm{H}_{6},{ }^{2} J_{\mathrm{HH}}=17.2,{ }^{3} J_{\mathrm{HH}}=4.6 \mathrm{~Hz}\right)$, $3.10(\mathrm{~s}, 1 \mathrm{H}, \mathrm{sp}-\mathrm{CH}), 4.25\left(\mathrm{~m}, 1 \mathrm{H}, \mathrm{H}_{3}\right)$, and $5.14\left(\mathrm{~m}, 1 \mathrm{H}, \mathrm{H}_{5}\right)$. Additional data used for preparing Table1 are presented in the supporting information section. ${ }^{16 \mathrm{~b}}$ In addition, an extended survey of these enzymes using various other solvents proved less effective: THF (PSL, CVL, CAL), benzene (PSL, CAL), pyridine (PSL, substilisin), isopropyl ether (CAL), and dioxane (CAL).

Enzymatic Acylation of 2a with Other Vinyl Esters. In a typical procedure, CVL $(10 \mathrm{mg})$ was added to a solution of $2 \mathrm{a}(10 \mathrm{mg}, 0.066 \mathrm{mmol})$ and vinyl ester $(0.6 \mathrm{mmol})$ in THF $(2.5 \mathrm{~mL})$ or neat vinyl ester $(2.5 \mathrm{~mL})$ as solvent as summarized in Table 2. The suspension was shaken at $45{ }^{\circ} \mathrm{C}$, and the progress of the reaction was followed by TLC. At $100 \%$ conversion the mixture was filtered and the solvent was removed under reduced pressure. After ${ }^{1} \mathrm{H}-\mathrm{NMR}$ analysis, the crude material was subjected to HPLC (Rainin Microsorb, 1

(16) (a) For all major products, full spectral data are given in the supporting information. Selected ${ }^{1} \mathrm{H}-\mathrm{NMR}$ signals are also presented in the Experimental Section. The purity of all major isomers or intermediates was estimated by a combination of HPLC and NMR analysis. The level of purity is indicated by the inclusion of copies of ${ }^{1} \mathrm{H}-\mathrm{NMR}$ spectra and ${ }^{13} \mathrm{C}-\mathrm{NMR}$ spectra in the supporting information. (b) Minor acylation products, the proportions of which were used in the preparation of Tables $1-5$, were analyzed as mixtures (using a combination of TLC, HPLC, and ${ }^{1} \mathrm{H}-\mathrm{NMR}$ analysis) together with the major products produced in the enzymatic reactions. Detailed data for minor products are also presented at the end of the supporting information section. 
$\times 25 \mathrm{~cm}, 5 \mu \mathrm{m}$ silica gel column, $25 \%$ ethyl acetate/hexanes, 4 $\mathrm{mL} / \mathrm{min}$ ) to give compounds $\mathbf{8 a}-\mathbf{d}$. The ${ }^{1} \mathrm{H}-\mathrm{NMR}$ data of $\mathbf{8 a}$ are given above. 8b: ${ }^{1} \mathrm{H}$ NMR $\delta 1.13\left(t, 3 \mathrm{H}, \mathrm{Me},{ }^{3} J_{\mathrm{HH}}=7.6\right.$ $\mathrm{Hz}), 2.03(\mathrm{~s}, 3 \mathrm{H}, \mathrm{Me}), 2.20\left(\mathrm{dd}, 1 \mathrm{H}, \mathrm{H}_{6},{ }^{2} J_{\mathrm{HH}}=17.1,{ }^{3} J_{\mathrm{HH}}=\right.$ $7.1 \mathrm{~Hz}$ ), $2.31\left(\mathrm{q}, 2 \mathrm{H}, \mathrm{MeCH}_{2},{ }^{3} \mathrm{~J}_{\mathrm{HH}}=7.6 \mathrm{~Hz}\right), 2.61\left(\mathrm{dd}, 1 \mathrm{H}, \mathrm{H}_{6}\right.$, $\left.{ }^{2} J_{\mathrm{HH}}=17.2,{ }^{3} J_{\mathrm{HH}}=4.9 \mathrm{~Hz}\right), 3.09(\mathrm{~s}, 1 \mathrm{H}, \mathrm{sp}-\mathrm{CH}), 4.26(\mathrm{~m}, 1 \mathrm{H}$, $\left.\mathrm{H}_{3}\right)$, and $5.16\left(\mathrm{~m}, 1 \mathrm{H}, \mathrm{H}_{5}\right)$. 8c: ${ }^{1} \mathrm{H}$ NMR $\delta 0.94(\mathrm{t}, 3 \mathrm{H}, \mathrm{Me}$ $\left.{ }^{3} J_{\mathrm{HH}}=7.4 \mathrm{~Hz}\right), 2.02(\mathrm{~s}, 3 \mathrm{H}, \mathrm{Me}), 2.19\left(\mathrm{dd}, 1 \mathrm{H}, \mathrm{H}_{6},{ }^{2} J_{\mathrm{HH}}=17.2\right.$, $\left.{ }^{3} J_{\mathrm{HH}}=7.2 \mathrm{~Hz}\right), 2.26\left(\mathrm{t}, 3 \mathrm{H}, \mathrm{EtCH}{ }_{2},{ }^{3} J_{\mathrm{HH}}=7.4 \mathrm{~Hz}\right), 2.60(\mathrm{dd}$, $\left.1 \mathrm{H}, \mathrm{H}_{6},{ }^{2} J_{\mathrm{HH}}=17.1,{ }^{3} J_{\mathrm{HH}}=4.9 \mathrm{~Hz}\right), 3.10(\mathrm{~s}, 1 \mathrm{H}, \mathrm{sp}-\mathrm{CH}), 4.25$ $\left(\mathrm{m}, 1 \mathrm{H}, \mathrm{H}_{3}\right)$, and $5.15\left(\mathrm{~m}, 1 \mathrm{H}, \mathrm{H}_{5}\right) .8 \mathrm{~d}:{ }^{1} \mathrm{H}$ NMR $\delta 2.03(\mathrm{~s}, 3 \mathrm{H}$, $\left.\mathrm{C}_{2}-\mathrm{Me}\right), 2.26\left(\mathrm{dd}, 1 \mathrm{H}, \mathrm{H}_{6},{ }^{2} J_{\mathrm{HH}}=17.1,{ }^{3} J_{\mathrm{HH}}=7.1 \mathrm{~Hz}\right), 2.65$ (dd, $\left.1 \mathrm{H}, \mathrm{H}_{6},{ }^{2} J_{\mathrm{HH}}=17.1,{ }^{3} J_{\mathrm{HH}}=5.0 \mathrm{~Hz}\right), 3.11(\mathrm{~s}, 1 \mathrm{H}, \mathrm{sp}-\mathrm{CH}$ ), $4.04\left(\mathrm{~s}, 2 \mathrm{H}, \mathrm{ClCH}_{2}\right), 4.30\left(\mathrm{t}, 1 \mathrm{H}, \mathrm{H}_{3},{ }^{3} J_{\mathrm{HH}}=4.1 \mathrm{~Hz}\right)$, and 5.25 $\left(\mathrm{m}, 1 \mathrm{H}, \mathrm{H}_{5}\right)$. Additional data used for preparing Table 2 are presented in the supporting information section. ${ }^{16 \mathrm{~b}}$

Enzymatic Acylation of $(3 R, 5 S)-3 b$ with Vinyl Esters. The procedure parallels that indicated above for obtaining the data given in Table 2. However, the results obtained for $\mathbf{3 b}$, summarized in Table 3 , were for reactions conducted at room temperature rather than at $45^{\circ} \mathrm{C}$. The ${ }^{1} \mathrm{H}-\mathrm{NMR}$ spectral data of $10 \mathbf{a}-\mathbf{d}$ are of course identical to those of $8 \mathbf{a}-\mathbf{d}$ given above. 10e: ${ }^{1} \mathrm{H}$ NMR $\delta 2.07(\mathrm{~s}, 3 \mathrm{H}, \mathrm{Me}), 2.38\left(\mathrm{dd}, 1 \mathrm{H}, \mathrm{H}_{6},{ }^{2} J_{\mathrm{HH}}=\right.$ $\left.17.3,{ }^{3} J_{\mathrm{HH}}=7.0 \mathrm{~Hz}\right), 2.74\left(\mathrm{dd}, 1 \mathrm{H}, \mathrm{H}_{6},{ }^{2} J_{\mathrm{HH}}=17.2,{ }^{3} J_{\mathrm{HH}}=4.9\right.$ $\mathrm{Hz}), 3.11(\mathrm{~s}, 1 \mathrm{H}, \mathrm{sp}-\mathrm{CH}), 4.36\left(\mathrm{t}, 1 \mathrm{H}, \mathrm{H}_{3},{ }^{3} \mathrm{~J}_{\mathrm{HH}}=4.8 \mathrm{~Hz}\right), 5.41$ (apparent $\left.\mathrm{q}, 1 \mathrm{H}, \mathrm{H}_{5},{ }^{3} J_{\mathrm{HH}}=6.3 \mathrm{~Hz}\right), 7.43(\mathrm{~m}, 2 \mathrm{H}, \mathrm{Ph}$ ), 7.56 $(\mathrm{m}, 1 \mathrm{H}, \mathrm{Ph})$, and $8.01(\mathrm{~m}, 2 \mathrm{H}, \mathrm{Ph})$. Additional data used for preparing Table 3 are presented in the supporting information section. ${ }^{16 b}$

$(5 R)$ - and (5S)-3-Ethynyl-5-hydroxy-2-methyl-2-cyclohexen-1-one (12a and $12 \mathrm{~b}$, respectively). To a mixture of the Dess-Martin periodinane reagent $(1.5 \mathrm{~g}, 3.75 \mathrm{mmol})$ in dry acetonitrile $(30 \mathrm{~mL})$ was added $2 \mathrm{a}(380 \mathrm{mg}, 2.5 \mathrm{mmol})$. The reaction mixture was stirred at room temperature for $1 \mathrm{~h}$ under argon, and then the resulting mixture was diluted with ether and washed with a 1:1 mixture $(\mathrm{v} / \mathrm{v})$ of saturated aqueous $\mathrm{Na}_{2} \mathrm{~S}_{2} \mathrm{O}_{3}$ and $\mathrm{NaHCO}_{3}$ solution. The organic layer was then dried $\left(\mathrm{MgSO}_{4}\right)$ and evaporated to dryness. The residue was purified by flash chromatography on silica gel using $45 \%$ ethyl acetate/hexanes to afford after vacuum drying $310 \mathrm{mg}(82 \%)$ of ketone 12a (or 12b): ${ }^{1} \mathrm{H}$ NMR $\delta 1.99(\mathrm{~s}, 3 \mathrm{H}, \mathrm{Me}), 2.48-$ $2.65\left(\mathrm{dd}, 1 \mathrm{H}, \mathrm{H}_{4},{ }^{2} J_{\mathrm{HH}}=16.3,{ }^{3} J_{\mathrm{HH}}=8.7 \mathrm{~Hz}+\mathrm{m}, 1 \mathrm{H}, \mathrm{H}_{6}\right)$ $2.72-2.90\left(\mathrm{dd}, 1 \mathrm{H}, \mathrm{H}_{4},{ }^{2} J_{\mathrm{HH}}=15.8,{ }^{3} J_{\mathrm{HH}}=4.0 \mathrm{~Hz}+\mathrm{m}, 1 \mathrm{H}\right.$, $\left.\mathrm{H}_{6}\right), 3.75(\mathrm{~s}, 1 \mathrm{H}, \mathrm{sp}-\mathrm{CH})$, and $4.31\left(\mathrm{~m}, 1 \mathrm{H}, \mathrm{H}_{5}\right)$. When the same procedure was applied to the enantiomer $\mathbf{3 b}$, essentially the same result was obtained except the reaction time had to be increased to $24 \mathrm{~h}$ (possibly due to decreased reactivity of oxidant).

Preparation of Cis Isomers (3R,5R)-2b and (3S,5S)-3a. Sodium borohydride $(1.3 \mathrm{~g}, 34 \mathrm{mmol})$ was added to an ice-cold solution of ketone $12 \mathrm{a}$ ( $302 \mathrm{mg}, 2 \mathrm{mmol})$ in methanol $(30 \mathrm{~mL})$. After stirring for $30 \mathrm{~min}$, the reaction mixture was extracted three times with ether and then the combined organic extract was dried $\left(\mathrm{MgSO}_{4}\right)$ and concentrated in vacuo. ${ }^{1} \mathrm{H}-\mathrm{NMR}$ analysis of the crude mixture showed a mixture of diastereoisomers $\mathbf{2 a}$ and $\mathbf{2 b}$ in the ratio $1: 3$. The diastereoisomers were separated by HPLC (Rainin Dynamax-60A, $2.14 \times 25$ $\mathrm{cm}, 8 \mu \mathrm{m}$ silica gel column, $95 \%$ ethyl acetate/hexanes, $8 \mathrm{~mL}$ $\mathrm{min})$ to give as the major product the cis isomer $2 \mathrm{~b}(207 \mathrm{mg}$, $68 \%$ ). $2 \mathrm{~b}$ (or 3a): ${ }^{1} \mathrm{H}$ NMR $\delta 1.86$ (ddd, $1 \mathrm{H}, \mathrm{H}_{4},{ }^{2} J_{\mathrm{HH}}=14.2$, $\left.{ }^{3} J_{\mathrm{HH}}=5.0,{ }^{3} J_{\mathrm{HH}}=2.1 \mathrm{~Hz}\right), 2.06(\mathrm{~s}, 3 \mathrm{H}, \mathrm{Me}), 2.13-2.24(\mathrm{~m}$, $\left.1 \mathrm{H}, \mathrm{H}_{4}\right), 2.25-2.52\left(\mathrm{~m}, 2 \mathrm{H}, \mathrm{H}_{6}\right), 3.02(\mathrm{br} \mathrm{s}, 1 \mathrm{H}, \mathrm{OH}), 3.10(\mathrm{~s}$ $1 \mathrm{H}, \mathrm{sp}-\mathrm{CH}), 4.04\left(\mathrm{~m}, 1 \mathrm{H}, \mathrm{H}_{5}\right)$, and $4.28\left(\mathrm{~m}, 1 \mathrm{H}, \mathrm{H}_{3}\right)$. The enantiomer $12 b$ under identical conditions afforded $\mathbf{3 b}$ and $3 \mathbf{a}$ in the same 1:3 ratio, and HPLC purification afforded cis isomer $\mathbf{3 a}$ also in $68 \%$ yield.

Enzymatic Acetylation of $(3 R, 5 R)-2 b$ and $(3 S, 5 S)-3 a$ with Vinyl Esters. The procedure was the same as described for obtaining the data given in Table 2. The data obtained

(17) Chen, C.-S.; Fujimoto, Y.; Girdaukas, G; Sib, C. J. J. Am Chem. Soc. 1982, 104, 7294.

(18) Parker, D. Chem. Rev. 1991, 91, 1441. for $3 a$ and $\mathbf{2 b}$ are summarized in Tables 4 and 5 , respectively. Both $3 \mathrm{a}$ and $\mathbf{2 b}$ were reacted at room temperature. Compounds 13a,c-d and 17a,c-d were purified by HPLC (Rainin Microsorb, $1 \times 25 \mathrm{~cm}, 5 \mu \mathrm{m}$ silica gel column, $20 \%$ ethyl acetate/hexanes, $4 \mathrm{~mL} / \mathrm{min})$. 13a: ${ }^{1} \mathrm{H}$ NMR $\delta 1.98-2.17(\mathrm{~m}$, $\left.8 \mathrm{H}, 2 \mathrm{Me}+\mathrm{H}_{4}\right), 2.33-2.54\left(\mathrm{~m}, 2 \mathrm{H}, \mathrm{H}_{6}\right), 3.11(\mathrm{~s}, 1 \mathrm{H}, \mathrm{sp}-\mathrm{CH})$, $4.09\left(\mathrm{~m}, 1 \mathrm{H}, \mathrm{H}_{3}\right)$, and $5.19\left(\mathrm{~m}, 1 \mathrm{H}, \mathrm{H}_{5}\right) .13 \mathrm{c}:{ }^{1} \mathrm{H}$ NMR $\delta 0.94$ $\left(\mathrm{t}, 3 \mathrm{H}, \mathrm{Me},{ }^{3} J_{\mathrm{HH}}=7.4 \mathrm{~Hz}\right), 1.63\left(\mathrm{~m}, 2 \mathrm{H}, \mathrm{MeCH}_{2}\right), 2.05(\mathrm{~s}, 3 \mathrm{H}$, $\mathrm{Me}), 2.27\left(\mathrm{t}, 2 \mathrm{H}, \mathrm{EtCH}{ }_{2},{ }^{3} J_{\mathrm{HH}}=7.5 \mathrm{~Hz}\right), 2.33-2.52(\mathrm{~m}, 2 \mathrm{H}$, $\left.\mathrm{H}_{6}\right), 3.10(\mathrm{~s}, 1 \mathrm{H}, \mathrm{sp}-\mathrm{CH}), 4.09\left(\mathrm{~m}, 1 \mathrm{H}, \mathrm{H}_{3}\right)$, and $5.21(\mathrm{~m}, 1 \mathrm{H}$, $\left.\mathrm{H}_{5}\right)$. 13d: ${ }^{1} \mathrm{H}$ NMR $\delta 2.06(\mathrm{~s}, 3 \mathrm{H}, \mathrm{Me}), 3.12(\mathrm{~s}, 1 \mathrm{H}, \mathrm{sp}-\mathrm{CH})$, $4.06\left(\mathrm{~s}, 2 \mathrm{H}, \mathrm{ClCH}_{2}\right), 4.10\left(\mathrm{~m}, 1 \mathrm{H}, \mathrm{H}_{3}\right)$, and $5.29\left(\mathrm{~m}, 1 \mathrm{H}, \mathrm{H}_{5}\right)$. 17a: ${ }^{1} \mathrm{H}$ NMR $\delta 1.90\left(\mathrm{~s}, 3 \mathrm{H}, \mathrm{C}_{2}-\mathrm{Me}\right), 2.09(\mathrm{~s}, 3 \mathrm{H}, \mathrm{Me}), 2.17$ (ddd, $\left.1 \mathrm{H}, \mathrm{H}_{4},{ }^{2} J_{\mathrm{HH}}=14.4,{ }^{3} J_{\mathrm{HH}}=5.8,{ }^{3} J_{\mathrm{HH}}=3.0 \mathrm{~Hz}\right), 3.15(\mathrm{~s}$, $1 \mathrm{H}, \mathrm{sp}-\mathrm{CH}), 4.03\left(\mathrm{~m}, 1 \mathrm{H}, \mathrm{H}_{5}\right)$, and $5.46\left(\mathrm{t}, 1 \mathrm{H}, \mathrm{H}_{3},{ }^{3} \mathrm{~J}_{\mathrm{HH}}=5.7\right.$ $\mathrm{Hz}) .17 \mathrm{c}:{ }^{1} \mathrm{H}$ NMR $\delta 0.96\left(\mathrm{t}, 3 \mathrm{H}, \mathrm{Me},{ }^{3} J_{\mathrm{HH}}=7.4 \mathrm{~Hz}\right), 1.67(\mathrm{~m}$, $2 \mathrm{H}, \mathrm{MeCH}_{2}$ ), $1.89\left(\mathrm{~s}, 3 \mathrm{H}, \mathrm{C}_{2}-\mathrm{Me}\right.$ ), 2.17 (ddd, $1 \mathrm{H}, \mathrm{H}_{4},{ }^{2} J_{\mathrm{HH}}=$ $\left.13.2,{ }^{3} J_{\mathrm{HH}}=5.7,{ }^{3} J_{\mathrm{HH}}=3.0 \mathrm{~Hz}\right), 2.31\left(\mathrm{t}, 2 \mathrm{H}, \mathrm{EtCH}_{2},{ }^{3} J_{\mathrm{HH}}=\right.$ $7.4 \mathrm{~Hz}), 3.15(\mathrm{~s}, 1 \mathrm{H}, \mathrm{sp}-\mathrm{CH}), 4.04\left(\mathrm{~m}, 1 \mathrm{H}, \mathrm{H}_{5}\right)$, and $5.47(\mathrm{t}, 1 \mathrm{H}$ $\left.\mathrm{H}_{3},{ }^{3} J_{\mathrm{HH}}=5.5 \mathrm{~Hz}\right) .17 \mathrm{~d}:{ }^{1} \mathrm{H}$ NMR $\delta 1.91(\mathrm{~s}, 3 \mathrm{H}, \mathrm{Me}), 2.22$ (ddd, $1 \mathrm{H}, \mathrm{H}_{4},{ }^{2} J_{\mathrm{HH}}=13.4,{ }^{3} J_{\mathrm{HH}}=5.9,{ }^{3} J_{\mathrm{HH}}=3.1 \mathrm{~Hz}$ ), $3.18(\mathrm{~s}$, $1 \mathrm{H}$, sp-CH), $4.06\left(\mathrm{~m}, 1 \mathrm{H}, \mathrm{H}_{5}\right), 4.08\left(\mathrm{~s}, 2 \mathrm{H}, \mathrm{ClCH}_{2}\right)$, and $5.53(\mathrm{t}$, $1 \mathrm{H}, \mathrm{H}_{3},{ }^{3} J_{\mathrm{HH}}=5.6 \mathrm{~Hz}$ ). Additional data used for preparing Table 4 and 5 are presented in the supporting information section. $16 \mathrm{~b}$

(5S)-1-Ethynyl-5-hydroxy-2-methyl-1-cyclohexene [(-)4]. To a solution of racemic alcohol $4(100 \mathrm{mg}, 0.734 \mathrm{mmol})$ in vinyl acetate $(17 \mathrm{~mL})$ was added CVL $(65 \mathrm{mg})$, and then the mixture was shaken at room temperature. The reaction was monitored by GC using a $25 \mathrm{~m}$ fused silica glass capillary column packed with methyl silicone (helium carrier gas at 16 psi; injector port temperature $150^{\circ} \mathrm{C}$; detector port temperature $200^{\circ} \mathrm{C}$ ). The temperature of the column was increased from 100 to $200^{\circ} \mathrm{C}$ at $4{ }^{\circ} \mathrm{C} / \mathrm{min}$. The retention times observed were $28.7 \mathrm{~min}$ for (-)-4 and $34.4 \mathrm{~min}$ for 19 . The reaction was stopped when $52 \%$ of the alcohol $( \pm)-4$ was converted into the acetate 19 (approximately $18 \mathrm{~h}$ ). The reaction mixture was filtered and the enzyme washed with methylene chloride. The solvent was removed, and the products were separated by flash column chromatography using silica gel (20\% ethyl acetate/ hexanes as eluent) to afford $(S)-(-)-4(46.5 \mathrm{mg}, 97 \%, \geq 97 \%$ $\left.\mathrm{ee}^{15}\right)$ and the acetate, enriched in $(R)-(+)-19(67.3 \mathrm{mg}, 99 \%$, $94 \%$ ee calculated after saponification as indicated below) [enantioselectivity, $E>100$ ]. ${ }^{17}$ Compound 4 was shown to be optically pure by a standard procedure ${ }^{18}$ by ${ }^{1} \mathrm{H}-\mathrm{NMR}$ spectroscopy using the chiral shift reagent Eu(hfc) ${ }_{3}\{$ tris [3-((heptafluoropropyl)hydroxymethylene)-(+)-camphorate]europium(III)\}. 4: ${ }^{1} \mathrm{H}$ NMR $\delta 1.58-1.72\left(\mathrm{~m}, 1 \mathrm{H}, \mathrm{H}_{4}\right), 1.78-1.96\left(\mathrm{~m}, 1 \mathrm{H}, \mathrm{H}_{4}\right)$, $1.89(\mathrm{~s}, 3 \mathrm{H}, \mathrm{Me}), 2.04-2.32\left(\mathrm{~m}, 3 \mathrm{H}, 2 \mathrm{H}_{3}+\mathrm{H}_{6}\right), 2.41-2.56(\mathrm{~m}$, $\left.1 \mathrm{H}, \mathrm{H}_{6}\right), 3.02(\mathrm{~s}, 1 \mathrm{H}, \mathrm{sp}-\mathrm{CH})$, and $3.96\left(\mathrm{~m}, 1 \mathrm{H}, \mathrm{H}_{5}\right) .19:{ }^{1} \mathrm{H}$ NMR $\delta 1.64-1.86\left(\mathrm{~m}, 2 \mathrm{H}, \mathrm{H}_{4}\right), 1.90(\mathrm{~s}, 3 \mathrm{H}, \mathrm{MeCO}), 2.03(\mathrm{~s}$, $3 \mathrm{H}, \mathrm{Me}), 2.11-2.30\left(\mathrm{~m}, 3 \mathrm{H}, 2 \mathrm{H}_{3}+\mathrm{H}_{6}\right), 2.42-2.57\left(\mathrm{~m}, 1 \mathrm{H}, \mathrm{H}_{6}\right)$, $3.02(\mathrm{~s}, 1 \mathrm{H}, \mathrm{sp}-\mathrm{CH})$, and $5.00\left(\mathrm{~m}, 1 \mathrm{H}, \mathrm{H}_{5}\right)$.

For the determination of the enantiomeric excess (ee) of the acetate $(R)-(+)-19$, the ester was reacted with sodium methoxide in methanol. The resulting alcohol $(R)-(+)-4$ was determined to be $94 \%$ ee according to ${ }^{1} \mathrm{H}$-NMR spectroscopy using $\mathrm{Eu}(\mathrm{hfc})_{3}$ as described above for $(S)-(-)-4$.

Acknowledgment. We express our appreciation to Genzyme Co. for a generous gift of CVL. Financial support from National Institutes of Health (Grant No. DK-16595) is gratefully acknowledged. M.F. also thanks the Ministerio de Educación y Ciencia of Spain for a postdoctoral fellowship.

Supporting Information Available: Spectral and analytical data ( 23 pages). This material is contained in libraries on microfiche, immediately follows this article in the microfilm version of the journal, and can be ordered from the ACS; see any current masthead page for ordering information. 